\title{
Cultural Geographies lecture
}

\section{Childhood as spectacle: relays of anxiety and the reconfiguration of the child}

\author{
Cindi Katz
}

Environmental Psychology Program, City University of New York

\begin{abstract}
As the 21st century picks up speed and settles into place, childhood has become a spectacle - a site of accumulation, commodification, and desire - in whose name much is done. In this article, I argue that the spectacle of childhood is associated with the rise of ontological insecurity provoked by anxieties around the political-economic, geopolitical, and environmental futures. I address how this spectacle is produced and made sensible, and lay out three configurations of the child - as accumulation strategy, ornament, and waste - that it calls forth. I suggest some of the consequences of these material social practices for actual children and the cultural geographies of their everyday lives. In exploring what is accomplished politically and socially by these cultural forms and material social practices, I draw out their connections with commodification, essence, distraction, and panic.
\end{abstract}

Keywords: Accumulation strategy $\bullet$ childhood $\bullet$ children $\bullet$ ontological insecurity $\bullet$ spectacle

Sectacle, according to French situationist Guy Debord, is the accumulation of capital to the $\checkmark$ point of collapse; where capital itself becomes image. As the 21st century picks up speed and settles into place, childhood has become a spectacle - a site of accumulation and commodification - in whose name much is done. In this article, I ask why and through what means this spectacularization has occurred, delineate three configurations of the child - as accumulation strategy, ornament, and waste - that it precipitates, and point to some of the consequences of these material social practices for actual children and the cultural geographies of their everyday lives. In exploring what is accomplished politically and socially by these cultural formations, I draw out their connections with commodification, essence, distraction, and panic.

Contemporary social life in the USA is riddled with ontological insecurity provoked initially by the threats to its presumptions of hegemony associated with the social movements of the 1960s and 1970s, the effects of decolonization, the oil shocks of 1973, and the military defeat in Vietnam, among other things. Along with the loss of bravado - so easily manufactured in the USA prior to these slow-motion setbacks - came the loss of innocence associated with the assassinations of the 1960s and Watergate. The 'stagflation' of the 1970s further dimmed the prospect of a secure future for many people, and the pressures of neoliberal 
capitalism, which off-loaded public and corporate responsibility for the social wage onto individuals and the institutions of civil society, made social life that much more precarious. Whereas my larger project closely examines these issues and their relationship to contemporary childhood and children's everyday lives in the USA, here I want to focus on the relay of these shifts in and through the social construction of childhood and children, leaving the historical geographies and everyday experiences of actual children in the background.

Ontological insecurity is associated with anxiety about the future, which is in part channeled in and through concerns about children and the nature of childhood. It seems to me that three modes of anxiety permeate contemporary everyday life in the USA producing an easily tapped sense of ontological insecurity that is expressed through various representations of childhood as spectacle. Anxiety about the political economic future - in which the terrain of employment has shifted profoundly but the social relations of production and work roles have not, the geopolitical future - in which U.S.-European presumptions of hegemony and rule are facing a serious threat that renders traditional boundaries porous and destabilized while ratcheting up the level of U.S. state violence internally and externally, and the environmental future - in which issues such as toxic environments and global climate change loom ever larger and are often experienced as exceeding people's capacity (or will) to control are managed in part by what I am referring to as the spectacle of childhood.

In this regard, my project has some parallels with the work of architectural theorist Beatriz Colomina whose recent book, Domesticity at War, argues that post World War II and cold war anxiety was masked and managed through the domestic, wherein the ethos and tyranny of complete control over home and lawn, for example, were means of absorbing (and distracting from) a pervasive sense of threat. ${ }^{1}$ Colomina draws out the parallels and intersections between domestic architecture and technologies, and those of the state at war, demonstrating their common origins and manufacturers, their complementary concerns, and the redirection of military technology and materials into the home and garden. Colomina's arguments, like mine, link the manufacture of the threat by the state and corporate capitalism to their interests in particular kinds of domestic development and projects that distracted the populace from social concerns and political economic worries.

Apart from these parallels, there is an historic connection between the issues detailed by Colomina and those that concern me here. The discipline of 'better homes and gardens,' and the quest for 'absolute control' over domestic details imploded in the 1960s and 1970s. Betty Friedan's Feminine Mystique tapped into the dissatisfactions and impossibilities of the quest for domestic perfection among middle and upper middle class women, helping to propel the women's movement and the not unrelated foundering of the hetero-normative nuclear family with rising divorce rates and attempts to change household dynamics. ${ }^{2}$ But it seems to me that the quest for perfection and complete control resurfaced in the next generation around children and childhood. Now we see anxiety around the political economic, geopolitical, and environmental future relayed into securing children's futures and producing perfect childhoods in ways that supplant and echo the complete control over the domestic identified by Colomina. These relationships (and their connection to the ideological work of the state and capital) are expressed in and through childhood as spectacle, and, as I suggest later, each arena of anxiety is connected to a particular figuration of the child.

Anxiety over the political economic future is channeled into the commodification of children. Anxiety over the geopolitical future surfaces in the unhinging of some of the 6 
boundaries between adults and children and adulthood and childhood, and more seriously in the securitizing of children's everyday lives. Finally, anxiety over the environment is channeled into all manner of attempts to control children's experiences and into rejigging the relationship between childhood and adulthood by pinning hopes for the resolution of contemporary problems recklessly on the adults of tomorrow - today's children. These spectacular constructions of childhood and the child mediate well-founded and increasingly widespread anxieties about the future. But as spectacle they work in the realms of the imaginary, of appearances, representation, and crisis; calling forth particular practices and thwarting others, but only tendentially and never completely. The material social practices that concern me as ever - are those of social reproduction, especially those focused on children. Practices like these are suffused with other sorts of relations like love, which both supplement and exceed the social relations of production and reproduction and can rework them. Before I address what I mean by childhood as spectacle, I want to mark my concern that framing the problem as 'anxiety' or even as 'ontological insecurity' may seem a diversion when we reflect on the levels of violence, oppression, and exploitation in the world. But anxiety is the raw material of spectacle - giving it 'legs', so to speak - and thus is an affective field of politics and its cultural formations. Understanding its work is then a political project.

Childhood, as has been well realized in the literature of virtually every social science and humanities discipline, is a social construction of multiple dimensions - as separate life stage, as itself internally segmented, as a reservoir of memory and fantasy, and as always mobile 'becoming' defines its limits. As such, childhood and youth have proven to be readily available for mobilization around moral panics and the definition of social ills. It is this aspect of childhood which is perhaps its most constant: that contemporary childhood (whenever 'contemporary' is) is fraught, and children are imperiled, impaired, and 'at risk,' whether from all manner of social problems that children are routinely seen as incapable of handling, or from the nature of youth itself. Childhood defines an always-incomplete state; when it is complete - if it ever is - it is no longer childhood. Its mobility is one of 'becoming,' and that fluidity opens it as a tremendously fertile figuration upon which all manner of things, ideas, affective relations, and fantasies are projected. ${ }^{3} \mathrm{I}$ am, of course, culpable of this as well. As I trace childhood as spectacle I am both recording and working through a figuration that I think is present with multiple consequences for both the contemporary social formation and lived experience, but I am also figuring childhood myself. Even as I recognize my participation in that problematic tradition, which feels almost impossible - and absurd - to refuse, I hear myself saying, 'yes, but now it really is different ...'. That recognition notwithstanding, it is all the more important to work through what does seem different in the current U.S. social formation.

The becomingness of children, which is almost tautologically the defining feature of childhood, ricochets around questions of the future and futurity itself. These are key to the power and seductiveness of childhood as a social construction. Claudia Castañeda's notion of the child as figuration comes into play here. Focusing on the work of Foucault, Blanchot, Deleuze and Guattari, and Lyotard, she raises critical philosophical questions about subjectivity. When the child is imagined as a blank slate or object of becoming - available thus to inhabitation by others - it is erased as 'bearer of experience." As subjects of becoming, however, children may be seen as incomplete and thus 'outside' in a way that it is constitutive of the normative subject. ${ }^{5}$ 
Childhood as social construct is also seductive as what Patricia Crain, following Adam Phillips, refers to as 'the last refuge of unexamined essentialism. ${ }^{6}$ This is a compelling and almost startling idea given how much work has been done to refuse and undermine essentialist understandings of subjectivity and of difference. Yet when it comes to children, we seem able to see them as innocent, as unformed, as savage, as 'good' or as vulnerable without historicizing, locating, or specifying their much more complicated unstable and contingent subjectivity. The recourse to essences triggers (as it is provoked by) the familiar affective zones associated with fear and nostalgia, which are, of course, connected modes of imagining future and past for which the child, childhood, and children are a ready fulcrum. Much of the nostalgia around childhood is spurred by memory; the child being the only subject position which all adults (putatively) are not but once were. It would seem that the specificity of individual memory would diffuse essentialism around childhood, but it does not. Even in the negative, memory seems to spawn a nostalgic notion of what childhood is or should be ideally, and this idealized notion tends to spur fear around the constitution of contemporary childhood, any 'contemporary' childhood. As Crain suggests, childhood as essence, at least privileged childhood, does the work of maintaining for adults a vision of a pastoral world as museum, with all the typical consequences and residues of museumification. It is for these reasons, among others, that childhood is so ripe for multiple figurations, including my own as spectacle.

The spectacle and the realms of the imaginary it calls forth, offer an extraordinarily productive way of understanding the desires, distractions, and derailments of the present moment. For Debord, the spectacle is capital accumulated to the point that it becomes image. ${ }^{7}$ It picks up on Marx's notion of the commodity as embodying and obscuring the social relations of production, and extends it so that the thing itself and having it are reduced to appearance. The image, in other words, exceeds the object. The spectacle marks a kind of alienation, separation, and passivity wherein, following on from Marx's ideas on commodity fetishism, the multiple strands through which culture is produced by capital, the media, and institutions of the state and market revolve around images, commodities, and events that enthrall, distract, or spur desire. These affective states can render social actors passive at the same time as they obscure the uneven effects of capital accumulation. Debord notes that under these conditions the relations among people are mediated by images so that the material social practices of creative transformation and even being alive become representations, almost inaccessible except through appearances, images, and the construction of events. The effects of these conditions, Debord suggests, are docility and distraction. With typical mordant humor, he called this state of being, 'permanent opium war.' In this vein, childhood as spectacle can be seen as both distraction and sump, siphoning social concerns into individual ones and marking the colonization of social realms such as everyday life, leisure, timespace, and affective relations by the commodity.

Given the discursive work done by childhood and spectacle in and of themselves, their work in concert suggests the following:

1. The commodification of social relations, including the deepest social relations - familial which at least raises the question of relations and practices that exceed or defy commodification. Here I include love, dreams, and desire, among others. 
2. A construction of 'the child' as a representation or an image, which, among other things, has the effect of obscuring the commodification of social relations.

In assessing the effects of these constructions it is crucial to remember Carolyn Steedman's admonition that children are not just repositories of adults' desires and fantasies, but also are subjects and social actors in their own rights. In this regard, it is important to keep in mind the connections between childhood, spectacle, and the unfolding lives of children in particular histories and geographies. Likewise, one of the critiques of the spectacle, which I share, is the tendency to see it as all-encompassing so that it seems to devour all agency and autonomous initiative. While it is not hard to be captured by the spectacular nature of the spectacle, it makes it all the more crucial to remember that the whole point of theorizing its apparatus and modes of distraction is to counter them with other forms of imagining. To be rendered passive in the face of the technologies that would make us passive is defeat squared. It is in the interests of subverting the spectacle that a look at childhood as spectacle is potentially fruitful, especially because childhood is a realm of everyday life that is suffused with social relations that can exceed commodification, evade colonization, and recreate the means of existence and subjectivity in new registers. I want to be clear that I am not reducing the spectacle to a self-immolating zone of false consciousness, but rather seeing in it a fertile arena of imagining and longing for making life different. Childhood as spectacle marks the power of desire that can be unleashed otherwise even as it is at the same time a social formation upon which an extraordinary arsenal of weapons of mass distraction is aimed.

Childhood as spectacle is materialized in various ways. In delineating some of these, I am approaching but not fully realizing the historical geographies of spectacular childhood. Fleshing out what some of these historical geographies are and how they are negotiated and inhabited in the course of children's everyday lives is part of the empirical project I plan to take on now that I have wrangled with the various modes of imagining childhood as spectacle. Among is effects are three interrelated configurations of the child: as accumulation strategy, as ornament, and as waste. These reflect respectively the spectacle's associations with commodification, essence, and distracting appearance and panic. Each materialization is associated with specific modes of embodiment and particular historical geographies. These are delineated in some detail later.

Children have long been the kind of investment suggested by casting them as an accumulation strategy. They were an economic asset to their households' production and reproduction and a means of securing the economic future for their parents and other members of the extended family. Children went from economic asset to liability in the global north as production was located increasingly outside the home, infant and child mortality decreased, and reproducing a differentiated labor force became attenuated. This shift - with class variations - was essentially complete with the baby boom generation. At the same time children became ever more psychic investments, which is not to say that children were not psychologically important in former times - of course they were - but their 'value,' especially as the likelihood of their survival was more secure, was increasingly psychological and emotional. In the current period, children are both an economic and psychic investment in the future. As such and exceeding it, children are a bulwark against ontological insecurity and 
other anxieties about the future, and it is here that the spectacular nature of children as an accumulation strategy can be seen most clearly. As the nature of the investment has shifted registers children themselves have been commodified to secure them. Each of these aspects of childhood as spectacle has particular consequences for children's lives and the material social practices of childhood as lived and imagined.

By noting the changing register of investment and accumulation in children I want to mark a path from the social to the individual to the social in the temporalities of childhood. While the tendency through much of the 20th century was to secure social reproduction socially (or at least there was effective pressure on the state and capital to do so), it has been one of the hallmarks of neoliberal and globalized capitalist production, to offload as much of this responsibility as possible onto individuals and private institutions. And so while it is well known that in the last 30 years the social wage has deteriorated as social reproduction has been increasingly privatized, the investment in children - as an accumulation strategy, that is, their realized value - seems more collectivized than in earlier periods. This seemingly paradoxical situation results in the increasingly individualized production of children, and among the privileged especially, this means hothouse children, at the same time as there is more and more collective reliance on this investment. The expected collective payoffs come in the form of ever more youthful consumership, expectations of world-saving, and various modes of paying to play, only now it is the children - grown - who will work while 'we' play.

I will explain. Under earlier regimes of capital accumulation, with expanding production there was a need for, and broad commitment to, reproducing a differentiated and growing labor force, and this called forth expanding investments in the social wage from all sectors, which was of course socially as much as individually realized in employment. As these conditions have changed with globalized production and new technologies of production (unaccompanied by changing work rules or significant alterations in the working day or year in the USA), there has been a retreat from commitments to the social wage on the parts of capital and the government. I have written elsewhere about this situation in relation to its underwriting the wholesale privatization of social reproduction and lubricating the rise of ontological insecurity, ${ }^{8}$ but here I want to address it in relation to the privatized production of children as accumulation strategies and in this regard investments secured through their commodification. While these phenomena may be most striking in privileged households, they are not limited to them.

Facing a limited and not apparently expanding work future, it is common for individuals and families to scramble to ensure that their children 'make it.' The child as commodity is niche-marketed to secure success in the insecure future. In its most extreme forms in the global north there is a super-saturation of resources in particular children. This saturation begins at conception, but I refrain from discussing the panoply of increasingly turbo-charged reproductive technologies drawn on in a world of children who for various complicated reasons are available for adoption, and will merely note the wild frontiers of bio-engineering intent on the production of genetically modified children - perhaps to be a future 'eugeneration $z$ '? Even sticking to the material social practices of everyday childrearing, we can readily see the saturation of parental, social, and economic resources in particular children. But it is in the realm of spectacle that the practices of what, after Clifford Geertz, I have begun to call 'parental involution' - the over-elaboration of the work (and play) of childrearing - are 
conjured. These material social practices tend not only to absorb parents almost to the limits of absorption, but to distract them, and thus divert attention from the political economic and other sources of their insecurities to address their symptoms. ${ }^{\text {? }}$

My use of this term is drawn from Geertz's provocative formulation of agricultural involution, wherein he looked at how the complexifying of rice cultivation practices diverted and individualized social and political economic concerns about land tenure, access to resources, and agency. I have used this notion before with regard to examining nature as an accumulation strategy, and I think it is analogously applicable to children in the current moment. ${ }^{10}$ Just as nature has increasingly become an accumulation strategy with consequent elaborations of its commodification and involutions of its modes of production and extraction, so too have children in the over-developed north.

Among the symptoms of parental involution are hothouse children and the saturation of resources that produce them. This combination can be seen, for example, in the attenuation of education for growing numbers of young people, and the many and increasingly strange effects of competition at younger and younger ages to get into schools seen as more likely to ensure success. In New York City - which may be the apogee of this sort of thing, but nevertheless puts in relief much that is symptomatic - there is intense competition among the bourgeoisie for places in prestigious pre-schools. If the concept of a prestigious preschool seems oxymoronic consider that there are now 'safety' pre-schools (good schools where acceptance is less fraught), 'deans of admissions' for pre-schools, and seminars or coaches for hire to assist parents in writing the essays about their children that are part of the application process. Expectant parents have been known to put their soon-to-be-born children on enrolment waiting lists, and there was a front-page news story not too long ago about an offer of insider trading information for places in a prestigious pre-school in Manhattan. These practices are rehearsed and exacerbated at each step along the way to postsecondary school, where the competition is each year more intense. The sense of competition is in part an artifact of itself - because so many high school students now apply to more than a dozen universities, it ensures that there will be more applicants and thus relatively fewer admitted to any one place, which heats up the sense of competition that much further. One result has been the ratcheting up of anxiety in many quarters, and with it the growth of industries that prepare students not for college, but for the testing and admissions procedures. Private SAT preparatory classes have become routine, but hot on their heels are individual consultants who charge exorbitant fees $-\$ 10,000$ is not unusual - to coach parents and children through the admissions gauntlet. If the imaginary of childhood's spectacle encourages these practices, so too is it bolstered by them.

Parental involution can also be seen in the phenomena associated with the by now widely recognized overscheduled child. By some measures, homework has increased more than 50 per cent in the last 25 years, while school and extracurricular sports have become less playful, more competitive, and increasingly seen as a means to an end. I am not referring here to the role of sports scholarships for low-income students as much as the role of sports and other after-school activities in grooming children for particular niches. Lacrosse, which is less common, may get a child further than soccer, for example. Likewise, all manner of private lessons are provided for privileged children who now may take something like Mandarin as well as the usual music or dance classes. A relatively new industry in summer programs has 
sprouted in the last few years. These programs afford teens from the global north an opportunity to volunteer in the global south, at great parental expense, as means of rounding out their experiences. While there is much in these programs that is laudable, virtually all concerned recognize that key to their popularity is what they add to aspiring students' résumés. Finally, babysitting and nanny services report that there is a growing demand for child-minders from certain parts of the world - most commonly from China or Spanishspeaking areas - in the hope that particular language and comportment skills seen as integral to future success become part of the child's everyday environment.

In another realm, children are increasingly diagnosed with a host of psychological problems, learning disabilities, and any number of affective and cognitive disorders, which are themselves often spectacularized descriptions of child behaviors that fall within the typical range of activity. 'Epidemics' of Attention Deficit, Hyperactivity Disorder, depression, bipolarity, Asperger's syndrome, and autism among children and teens are given frequent attention in the popular press. These diagnoses have led to a growing number of medicated children of all classes, reflecting parental anxiety over perceived imperfections and the need to meet school and other institutions' benchmarks of achievement and standards of normal behavior. In some cases, parents strive to have their children diagnosed with a mild learning disability, as it will win them extra time on standardized tests and other forms of assistance in meeting academic goals. But the reliance on medication also rehearses the broader trend in the USA to medicate rather than treat psychological issues and further demonstrates the creeping pharmaceuticalization of everyday life.

Each of these arenas of practice around children is meant to groom their competitive advantage, casting them as an accumulation strategy. But given the relentlessness of these practices as cultural forms, they also affect the child's production of self and propel the erosion of one of the cherished hallmarks of childhood, the intrinsic nature of its pleasures. Many young people, for example, now appear to be increasingly strategic in the things they take on and do, making sure to do things for the sake of appearance as much as if not more than for the experience itself. The rise of programs to volunteer in exotic locations, for example, is a marker of this trend. But in a broader sense, the practices associated with childpackaging - no matter in whose hands - always already play out against the figuration of the child 'at risk,' and the specter of a wasted childhood or the child as waste. This figuration reminds that access to the value accumulated in the child has been refashioned in the contemporary period. The 'return' to parents is often psychic. Given that most families in the USA do not rely on their children for economic support, the reward comes from producing a commodity of great value, their sense of accomplishment in reaching toward 'perfection,' and the narcissistic pleasure of their investment realized.

At the same time, the return on children's value is realized socially through their drastically increased consumership, both as consumers in their own rights and as advisers for family consumption decisions. But beyond consumption, children coming of age as ever assume responsibility for the production and work of the future necessary to maintain the economy, but also the expectations of 'our' adulthoods and retirement. Finally, the individualized investments in children as accumulation strategies are realized socially through some inchoate sense or fantasy wish-dream that they actually will 'save the world' or at least save us from ourselves and the consequences of our actions or inactions. Who, then, has an investment in 
'childishness' in the sense of presentism and irresponsibility? And how much does this psychic investment help to mobilize panics around children and youth? The twinning of the rhetoric of 'for the children' or 'for the sake of our grandchildren' and the extraordinary effort to forestall the consequences of tax cuts, war, and environmental degradation is another driving force of spectacle. It suggests a blurring of boundaries between adults and children, as much as between adulthood and childhood that fetishizes 'the child,' and so can be linked to the spectacle in a different way.

The fetishization of the child and of childhood produces and is itself promulgated by spectacular representations of childhood as unfettered and free, which creates different sorts of blurred boundaries. If one of the enduring received notions of childhood is that it is a time of freedom, play, and dreams, it is apparent that adults increasingly make this vision impossible to realize. The tension between the ideal and the material here is resolved in the spectacle of all manner of childhood troubles. Yet at the same time, one of the prime lures of retirement replays the fantasy of childhood's freedom. In a single newspaper on a random day I saw an advertisement for retirement with the tagline, 'we don't know when childhood ends but we know when it begins again', a plea to 'save the oceans' that floated next to an angelic child's face, and an article that described a new line of cool golf carts that were custom made to look like Mustangs and other cars to entice boomer retirees. If the essence of childhood - and part of its draw as spectacle - is that it is a transitory phase, a 'becoming,' what might be the effects - on identity formation or public policy invoking a sense of responsibility for the future or sacrifice for the present, for example - of adulthood being the transitory phase between modes of childhood? What would be the material effects of a literal 'becoming-child' as Deleuze and Guattari have theorized? ${ }^{11}$ These ideas raise boundary issues that have not been well explored in the literature on children or the meaning of childhood. These issues are overlain on other blurred boundaries that may be easier to see. Among them, the constant breaching of young people's autonomy by 'helicopter parents,' the popularity of youthful fashions for adults coupled with a growing predilection for adult-looking baby and children's clothes, and the extraordinary rise in bodywork so that aging people appear "forever young." 12 Each of these boundary concerns is associated with the fetishization of the child as commodity, but also as ornament.

The child as ornament works on several levels that materialize childhood as spectacle. First, in an almost literal sense, babies these days are frequently portrayed as if baubles. A recent fashion spread in The New York Times Magazine, for example, posed a plump baby clad solely in a disposable diaper with a vampirical model wearing clothing with an average price over $\$ 3700 .^{13}$ The leggy model did not look like she had been pregnant any time in the recent past, nor did the clothes look like they could survive a splat of food, puke, or poop, to say nothing of their cost, all the more prohibitive for most new parents who so often are in the vortex of baby-oriented hyper-consumption. Then there was a style page article a couple of years ago that proclaimed children to be 'the hot new accessory' in the Hamptons. Witness the competitive world parenting of Angelina Jolie and Brad Pitt versus Madonna, which is not easily separable from the baby as bauble, humanitarian concerns notwithstanding. In this sense, children as ornaments are a materialization of childhood as spectacle that enhances and brings greater value to their possessors, and in these practices we see image capitalism in stark relief. 
But I also want to look at children as ornaments in the sense conveyed by Scott Montgomery in his insightful piece in National Geographic that framed the 'world as ornament." ${ }^{\text {'14 }}$ Ornament here refers to the museumification of the world, wherein there is a flattening of historical and geographical specificity that enables the projection of essences onto the object. And so it is with the child as ornament. As Stuart Aitken notes in a piece on the manufactured global crises of childhood, 'the otherness and peculiarity of children are rendered safe and manageable for programmatic research and instrumental notions of justice. ${ }^{15}$ The child as essence or ornament evokes 'the child' as innocent figure - its innocence always under siege. Lee Edelman, in his provocative book, No Future, claims 'the child' as innocent figure is a 'disciplinary image' that performs the 'mandatory cultural labor of social reproduction. ${ }^{.16}$ This labor is emphatically not the differentiated, frustrating, exhausting, and exhilarating labor of bringing up actual children, but the short-circuiting of adult desire and difference, affective limitations and possibilities, into 'the child' as essence or ornament and what Edelman calls 'the shrine of the sacred child.' The boundary issues arise again but in a different guise and register.

I am suggesting that 'the compulsory narrative of reproductive futurism,' to use Edelman's phrase, is fueled by the iteration of childhood as spectacle through the child as ornament. If, on the one hand, the essential invocations of 'the child' as ornament elicit the material social practices associated with reproductive futurism, on the other hand, they call forth 'the future' itself as under siege. This future, with its myriad attendant anxieties, is addressed and coped with increasingly through strategies that strive for, and of course do not achieve, absolute control over childhood along the lines addressed by Colomina regarding the domestic. I have addressed some of these strategies in my work concerning parental hypervigilance. ${ }^{17}$

The child as waste is in many ways the constitutive outside of the preceding two figurations of the child - as accumulation strategy and as ornament. Not only is the child as waste that which exceeds the commodified child, but as such this figuration helps to construct the generalized panic around young people at all scales of their existence. Moreover, the child as waste rehearses and revolves around the tropes of childhood innocence that are essentialized in constructions of the child as ornament. The spectacles of 'wasted youth' - which of course redound around a huge field of meanings - and youthful non-innocence (whether sexual, medicated, jaded, consumerist, criminal, violent, or otherwise) create a broad and open-ended terrain for intervention, both material and spectacular. Through this intervention the social order is produced, reproduced, maintained, and given meaning.

The child as waste is a figuration for the cultural forms and practices associated with these interventions, and helps to fortify - as it is fortified by - the other two materializations of childhood as spectacle. Here I am not addressing the excessing of actual young people or the ways their waste is maintained and managed through the military, the prison system, the multiple 'crises' of youth, education, drugs, violence, and the like, the welfare system, and what demographers call 'excess mortality' among young people. But each of these modes of waste management figures in constructions of childhood as spectacle, giving urgency to the strategies it calls forth around the commodification and niche marketing of children. This urgency - and its myriad sources in the present period - is all too real, which is why the 
construction of childhood as spectacle has so many overlapping registers with so much resonance for so many. This resonance and the material social practices it elicits drive my concern with refusing this spectacle and rechanneling its claims on our hearts and minds in other directions that might help define a new political terrain.

The deep anxieties and ontological insecurity provoked by contemporary political economic, geopolitical, and environmental conditions are increasingly channeled into the production and reproduction of certain modes of framing childhood and thus materialized in the bodies and historical geographies of particular children. For many reasons, which I hope I've made clear, childhood and its figurations of the child are fertile fields for sowing the seeds of distraction associated with the spectacle. Rather than cast - or castigate - parents and others drawn in by these constructions of childhood and children as misguided, I want to understand what drives their spectacular absorptions. To merely conclude that they are distracted by false promises and in false consciousness would be to accede to the spectacle's totalizing power, which is precisely not the point. Rather, I want to be part of a politics that respects and makes good on the intensity of concern within and about the family (understood broadly as a fluid congeries of social relations that involve love and care and the work of social reproduction that are not not economic, but are not solely so) regarding, among other things, the security and well-being of its members in the present and over the long haul, the future as something at once made and uncertain, and the levels of violence, economic uncertainty, and injustice encountered in everyday life. These are among the concerns that give childhood as spectacle so much resonance and make securing childhood so urgent. It suggests an enormous field for political organizing, and for imagining alternative routes to countering the sources of anxiety, insecurity, and fear that seem so prevalent in the present conjuncture. These issues raise the counterintuitive notion of 'ethical spectacle,' which starts from the premise of the spectacle's attraction and draw, and seeks to rework them rather than foreclose them as wrongheaded and beside the point. ${ }^{18}$

The practices I have been tracing regarding childhood as spectacle are largely in the realm of everyday life, where I have suggested that loving and caring for children is both inside and outside the social relations of production and reproduction in a political economic sense. This pivotal position makes these material social practices vital realms for reworking social relations and practices of all kinds. As Charles Acland suggests, politicizing everyday life calls for uncovering the suffusion of social relations in the mundane. ${ }^{19}$ Taking off from there it is possible to change its very grounds. Indeed, this was Debord's point in theorizing the spectacle - at least before he was engulfed in the totalizing matrix he made of it. As he put it, 'it is the urgent business of everyday life to recover the full potential of human power through revolutionary change.' For me, and particularly with regard to the concerns of childhood as spectacle and the everyday practices of social reproduction, some of the sparks of revolutionary change can be found in, recovered from, and enacted during childhood. Drawing on Benjamin, Buck-Morss, and Taussig, I have written elsewhere about the mimetic quality of children's play, wherein in the rehearsal and copying of various material social practices and cultural forms, children enact and can realize that social life is made and thus can be made differently. ${ }^{20}$ Some of the sparks of change amidst the routine reside there. 


\section{Acknowledgements}

This article was presented originally as the Cultural Geographies lecture to the annual conference of the Association of American Geographers in San Francisco, April 2007. Thank you to Mona Domosh for inviting, hosting, and encouraging me in her typically playful and generous way. I am grateful for the questions and comments of audience members in San Francisco and later at the Conference on Geographies of Children, Youth, and Families, Reading University. I am grateful to the Radcliffe Institute for Advanced Study for supporting this work. Thank you to Eric Lott who found all the slippages and soft spots in this essay. While I couldn't get rid of all of them here, I now know what I've got to do - or face the spectacle of dance camp.

\section{Biographical note}

Cindi Katz teaches at the Graduate Center of the City University of New York. Her book, Growing Up Global: Economic Restructuring and Children's Everyday Lives, won the AAG Meridian Award in 2004. Her current projects include a study of contemporary U.S. childhood, research on the intertwined spatiality of homeland and home-based security, and looking at social reproduction and the aftermath of Hurricane Katrina. She can be contacted at: Environmental Psychology Program, City University of New York, 365 Fifth Avenue, New York, NY 10016, USA; email: ckatz@gc.cuny.edu

\section{Notes}

1 B. Colomina, Domesticity at war (Cambridge, MIT Press, 2007).

2 B. Friedan, The feminine mystique (New York, Dell, 1963).

3 C. Castañeda, Figurations: child, bodies, worlds (Durham, Duke University Press, 2000).

4 Castañeda, Figurations, p. 146.

5 Ibid.

6 P. Crain, 'Childhood as spectacle', American literary bistory 11 (1999), pp. 545-53.

7 G. Debord, Society of the spectacle (Detroit, Black and Red, 1983).

8 C. Katz, 'Vagabond capitalism and the necessity for social reproduction', Antipode 33 (2001), pp. $708-27$.

9 C. Geertz, Agricultural involution: the processes of ecological change in Indonesia (Berkeley, University of California Press, 1969).

10 C. Katz, 'Whose nature, whose culture: private productions of space and the "preservation" of nature', in B. Braun and N. Castree, eds, Remaking reality: nature at the millennium (London, Routledge, 1998).

11 G. Deleuze and F. Guattari, A thousand plateaus: capitalism and schizophrenia (Minneapolis, University of Minnesota Press, 1987); G. Deleuze and F. Guattari, Kafka: toward a minor literature, (Minneapolis, University of Minnesota Press, 1986).

12 S. Ruddick, 'The politics of aging: globalization and the restructuring of youth and childhood', Antipode 35 (2003), pp. 334-62.

13 'Oh baby,' The New York Times magazine, 25 March 2007, pp. 54-9.

14 S. L. Montgomery, 'The world as ornament: thoughts on National Geograpbic', Central park 13 (1988), pp. $71-80$.

15 S. C. Aitken, 'Global crises of childhood: rights, justice and the unchildlike child', Area 33 (2001), p. 119. 
16 L. Edelman, No future: queer theory and the death drive (Durham, Duke University Press, 2004), p. 19.

17 C. Katz, 'The state goes home: local hypervigilance and the global retreat from social reproduction', Social justice 28(3) (2001), pp. 47-56; C. Katz, 'Me and my monkey: what's hiding in the security state', in M. Sorkin, ed., Indefensible space: the architecture of the national insecurity state (New York, Routledge, 2007).

18 See S. Duncombe, Dream: re-imagining progressive politics in an age of fantasy, (New York, New Press, 2007). Thank you to Paul Routledge for leading me to this work, sharing his ideas about ethical spectacle, and the inspiration of his 'insurgent clowning.'

19 C. Acland, Youth, murder, spectacle: the cultural politics of 'youth in crisis' (Boulder, Westview Press, 1994).

20 S. Buck-Morss, The dialectics of seeing: Walter Benjamin and the arcades project (Cambridge, MIT Press, 1989); M. Taussig, Mimesis and alterity: a particular bistory of the senses (London, Routledge, 1993); C. Katz, Growing up global: economic restructuring and cbildren's everyday lives (Minneapolis, University of Minnesota Press, 2004). 